\title{
OS CAMINHOS A SEREM PERCORRIDOS NA POESIA DE ALBERTO CAEIRO: UMA ABORDAGEM SEGUNDO A ESTÉTICA DA RECEPÇÃO
}

\author{
Fabrício César de Aguiar \\ Universidade Estadual de Maringá
}

\begin{abstract}
Resumo: A análise aqui proposta irá se embasar nos conceitos da Estética da Recepção, visando estudar o poema VIII - Num meio-dia de fim de primavera, de Alberto Caeiro, tendo como enfoque a valorização dos aspectos sensoriais do texto, principalmente o visual. Serão destacados os recursos poéticos utilizados para a construção do texto, bem como sua recepção pelos leitores. A análise será embasada nos conceitos teorizados por Wolfgang Iser, como: a interação entre o texto e o leitor e sua postura no momento de recepção; os lugares vazios e as estruturas de negação e negatividade; a abordagem da leitura como um ato por parte do leitor, o qual será o responsável pela concretização deste efeito e pela criação do "prazer estético", conceito este que será embasado na teoria de Hans Robert Jauss.
\end{abstract}

Palavras-chave: Estética da recepção. Poesia portuguesa. Interação entre texto e leitor

\section{Introdução}

O artigo em questão será centralizado no estudo pormenorizado do poema VIII Num meio-dia de fim de primavera, presente na obra $O$ Guardador de Rebanhos, de Alberto Caeiro embasado nos conceitos da estética da recepção, tendo como enfoque a valorização dos aspectos sensoriais do texto, principalmente o visual, destacando-se o recurso da plasticidade poética e os principais recursos utilizados para sua construção, assim como a recepção pelos leitores.

No que se refere à plasticidade e ao aspecto sensorial da linguagem do texto literário, nota-se que estes efeitos não se restringem apenas aos textos poéticos, pois também estão presentes nos texto em prosa, mesmo que com menor frequência. No entanto, é no texto poético que, geralmente, estes traços se apresentam com maior intensidade, como afirma 
Moisés (1987, p. 44), quando comenta em relação à poesia, que "não é de sua natureza narrar, mas sugerir, evocar, descrever ou projetar emoções, sentimentos e conceitos a um só tempo."

No que se refere aos pressupostos da Estética da Recepção, mais especificamente sobre os conceitos teorizados por Wolfgang Iser, serão destacados pontos como: a interação entre o texto e o leitor e sua postura no momento de recepção; a maneira como se caracterizam os lugares vazios e as estruturas de negação e negatividade no poema em questão; a abordagem da leitura como um ato por parte do leitor, o qual será o responsável pela concretização deste efeito e pela criação do "prazer estético", conceito este que será embasado na teoria de Robert Jauss.

Para isso, é fundamental pensar na interação entre o texto e o leitor, visto que o texto só se concretiza no momento da leitura, ato necessário para que a mensagem expressa possa ser transmitida e efetivada. Como afirma Iser (1999, p. 09), "O texto inicia sua própria transferência, mas esta só será bem sucedida se o texto conseguir ativar certas disposições da consciência. [...] O texto estimula os atos que originam sua compreensão". Sendo assim, para que ocorra o evento comunicativo é essencial que o leitor decifre os códigos empregados na construção do texto, uma vez que o processo de leitura contemple uma interação dinâmica entre texto e leitor. Este processo possui alguns hiatos, também vistos como lugares que podem ser ocupados pelo leitor. Para Iser (1999, p. 10) "é antes de tudo esse hiato que origina a criatividade da recepção". Esse recurso assemelha-se com as estruturas de negação, conceito que será explicado posteriormente.

Então, por existir lacunas e alguns lugares vazios no texto, não é possível estabelecer um perfeito equilíbrio entre o texto e o leitor, caracterizando assim uma relação assimétrica. É por este motivo que Iser (1999, p. 97) afirma que "sendo uma atividade guiada pelo texto, a leitura acopla o processamento do texto com o leitor; este, por sua vez, é afetado por tal processo. Gostaríamos de chamar tal relação recíproca de interação".

Esta atividade necessita ativar mecanismos de significação na mente do leitor no ato de leitura. É por este motivo que, para Iser (1999, p. 172), a relação entre texto e leitor "precisa ser de certa maneira guiada, pois o leitor está aquém do texto". Para que isso ocorra, o texto é composto através de estratégias que regem sua organização estrutural, a qual sugere ao leitor quais as possíveis trilhas a serem tomadas naquela leitura. Assim, segundo Iser (1996, p. 159), "as estratégias regulam no texto a organização dos elementos do repertório e asseguram as condições de recepção". 
Para esta organização, contribuem alguns "esquemas" que passam a serem os primeiros códigos do texto - os signos simbólicos convencionados para a constituição da mensagem. Geralmente tais esquemas possuem algo que ainda o leitor não possui e que não está familiarizado, podendo-se considerar como algo novo. Desta forma, este primeiro código denota as condições de apreensão, visto que o leitor que não domina este código não conseguirá efetivar a leitura.

Há, por sua vez, um segundo código produzido pelo leitor e orientado pelas convenções socioculturais que valem para cada leitor, possuindo, assim, uma carga subjetiva. Torna-se essencial que estes signos convencionais produzam uma correspondência entre o ficcional, o objeto artístico criado, e as condições fundamentais de apreensão do sujeito para que ocorra a transmissão da mensagem, ou seja, o leitor sempre terá como terá como parâmetro para o entendimento da mensagem, o mundo real em que ele está inserido. É o que destaca Eco, ao perceber que

$\mathrm{Na}$ verdade, os mundos ficcionais são parasitas do mundo real, porém são com efeito "pequenos mundos" que delimitam a maior parte de nossa competência do mundo real e permitem que nos concentremos num mundo finito e fechado, muito semelhante ao nosso, embora ontologicamente mais pobre. (ECO, 1994, p. 91)

Porém, pensando nas leituras possíveis a serem feitas através do parâmetro de mundo dos leitores, é de suma importância destacar que o texto fictício possui algumas estruturas que acabam direcionando as possíveis leituras, restringindo assim a possibilidade de toda e qualquer leitura aleatória e desordenada em relação às estruturas comunicativas. Conforme Iser,

É preciso que a atividade do leitor seja de alguma maneira controlada pelo texto [...] [visando] pôr em movimento a interação entre texto e leitor e iniciar um processo comunicativo, cujo sucesso é indicado pela constituição de um sentido. (ISER, 1999, p. 104)

Um dos recursos para a criação deste processo comunicativo entre texto e leitor tratase da negação, a qual se refere à quebra dos caminhos tradicionais e às possíveis lacunas criadas no texto. A negação

Atribui ao leitor um lugar entre o "não mais" e "ainda não". Ao mesmo tempo dá concretude ao lugar do leitor; A atenção do leitor aumenta pelo fato de que as expectativas evocadas em presença do que é familiar são paralisadas pela negação; (ISER, 1999, p. 171)

Deste modo, o leitor será estimulado a interagir com o texto, o que faz com que este recurso seja, para Iser (1999, p. 172), “um impulso decisivo para os atos de representação do 
leitor, estimulando-o a constituir um tema não formulado e não dado da negação enquanto objeto imaginário".

Conforme Iser (1999, p. 184), estas estruturas de negações "formam o relé comunicativo no texto, por meio do qual a negação do que é familiar se traduz em experiência para o leitor." A isto se associa o conceito de negatividade, no qual

\begin{abstract}
Os lugares vazios e as negações provocam uma peculiar condensação em textos ficcionais, pois a omissão e a suspensão indicam que praticamente todas as formulações do texto se referem a um horizonte não-formulado. [...] Daí se segue que o texto formulado é duplicado pelo que não está sendo formulado. Chamamos tal duplicação de negatividade de textos ficcionais. [...] Falar dessa duplicação enquanto negatividade resulta primeiro do fato de que ela, ao invés das formulações do texto, não é formulada, e, segundo, de que ela, ao invés da negação, não nega as formulações do texto. [...] Ao contrário, sendo o não-dito, ela constitui o dito; o fundamento constitutivo do dito se manisfesta por meio de lugares vazios e negações [...] as formulações do texto se expandem graças à negatividade (ISER, 1999, p. 191).
\end{abstract}

Desta forma, o lugar vazio induz o leitor a agir no texto. Então o leitor irá completar as lacunas de maneira abstrata e subjetiva, visto que estas lacunas criam algumas possibilidades de leituras e de formulação de enunciados comunicativos.

Após a realização da interação entre texto e leitor, considerando-se a leitura como um ato, tanto para complementação dos vazios do texto quanto para as relações entre as estruturas de tema e horizonte, o leitor atuará com as suas representações a fim de constituir o sentido da obra lida. O leitor transformado (que já não é mais o mesmo) completa a leitura com suas experiências modificadas em algum aspecto. Entende-se por esta transformação o conceito de efeito estético, o qual, segundo Iser, torna-se importante a observação de que a primeira e principal condição do "efeito" é a sua recepção pela "compreensão na sucessão de seus versos, sua narração ou o seu deslocamento dramático". O segundo passo é a interpretação, denominada por Jauss de "concretização de uma significação especifica", ligada à primeira leitura, mas com tarefa objetiva e mais direcionada ao esclarecimento da construção do texto (as condições verbais e poéticas) que orientam e conduzem a compreensão. A última etapa é a aplicação, na qual as anteriores estão incluídas, na medida em que representam o interesse de transpor o texto fora de seu passado ou dentro de seu presente, formando um julgamento estético que persuada, convença com precisão os possíveis intérpretes.

Desta forma, para Iser (1996, p. 53),

Se o efeito estético significa o que advém ao mundo por ele, então ele é não-idêntico ao de antemão já existente no mundo. Ao mesmo tempo, porém, compreendemos 
por que se atribuem traços característicos o não-idêntico a algo familiar e compreensível. Quando isto sucede, o efeito desaparece; pois esse efeito é só efeito, enquanto o que é significado por ele não se funda em nada senão nele mesmo. [...] Se o texto ficcional existe graças ao efeito que estimula nossas leituras, então deveríamos compreender a significação mais como um produto de efeitos experimentados, ou seja, de efeitos atualizados do que como uma idéia que antecede a obra e se manifesta nela.

Sendo assim, como o efeito estético só existe após a leitura concretizada pelo leitor, será após este ato que se possibilita o surgimento do prazer estético, o qual não se encontra no plano do texto, uma vez que é formado pelo leitor de maneira subjetiva.

O grande nome a teorizar sobre este conceito é Hans Robert Jauss, o qual, ao lado de Wolfgang Iser, é considerado um dos principais teóricos da Estética da Recepção. Iser preocupou-se mais com o que diz respeito ao texto e suas estruturas, tendo sido complementado por Jauss, que contribuiu com a parte histórica e externa do texto, valorizando a experiência de uma compreensão atenta dos recursos que colaboravam para a criação do distanciamento estético e posicionamento crítico do receptor dos textos. É por este motivo que a afirmação de Jauss faz-se necessária:

Só partir de Brecht pode-se falar de uma consideração do efeito da literatura, embora com a intenção de educar o receptor no sentido de uma postura racional e crítica, contra a tendência deste em favor de uma empatia (Einfuhlung) prazeirosa e de identificação estética. (JAUSS, 1979, p. 72)

Esta postura racional e crítica, associada ao teatro de Bertold Brecht, se deve aos recursos técnicos criados pelo dramaturgo para alcançar este posicionamento crítico por parte da platéia. São característicos alguns recursos como: a permanência da luz do teatro ligada na platéia durante o espetáculo teatral; a quebra frequente na trama, com os atores chamando a atenção da platéia de várias maneiras, às vezes repreendendo alguém que entre no decorrer da peça, causando o riso do público, por exemplo, ou a troca do cenário sendo este montado aos olhos do expectador, etc. Estes recursos servem para diminuir a distância estética entre a platéia e o espetáculo, e, assim, aumentar o posicionamento crítico dos expectadores. Com este objetivo, constrói-se a apresentação teatral para esta seja exposta de maneira que fique evidente que aquilo que estava sendo encenado ali se trata de algo fictício, que está sendo representado para que seja pensado criticamente pelo expectador.

Porém, para alcançar o efeito esperado, era necessário ser sutil para fazer com que este distanciamento do expectador não causasse o desinteressasse do mesmo em relação ao objeto estético representado, pois 
A atitude estética exige que o objeto distanciado não seja contemplado desinteressadamente, mas que seja co-produzido pelo fruidor à semelhança do que se passa no mundo imaginário, em que entramos como co-participantes - como objeto imaginário. (JAUSS, 1979, p. 75)

\title{
Desenvolvimento
}

Para iniciar a análise, é válido um breve comentário sobre Alberto Caeiro, um dos heterônimos criados pelo poeta Fernando Antônio de Nogueira Pessoa (1888-1935), sendo este poeta considerado pela crítica um dos grandes poetas da literatura universal. Sua arte é marcada por muitos traços geniais, dentre eles a criação de heterônimos, os quais segundo Quadros

\begin{abstract}
representam muitas coisas ao mesmo tempo: apaixonada procura da identidade, para além da máscara convencional de "uma" libertação e sublimação dos "tempos seres"; [...] processo "alquímico" interior de inicialização psíquica; forma de projeção-ocultação, fundamental para um homem secreto como Pessoa; modo sui generis de intervenção literária, intelectual e mesmo espiritual no mundo sociocultural português; jogo, simulação e engano face ao outro radical que todos os seus conviventes e contemporâneos eram para o poeta; expressão da originalidade existencial e psicológica do escritor; enfim, fenomenologia necessária e dialética de sua "maneira de ser" ou da sua onticidade, exigente de uma constante e labiríntica desvelação introspectiva. (QUADROS, 1984, p. 116)
\end{abstract}

Dentre os heterônimos que representam outras personalidades (chegam a totalizar mais de setenta na produção do poeta), merecem destaque Alberto Caeiro, Ricardo Reis e Álvaro de Campos, completos e valorizados pela crítica especializada. Pretenso mestre dos outros heterônimos e do poeta ortônimo, Alberto Caeiro surge no cenário literário como um homem de visão ingênua, instintiva e entregue às sensações, principalmente as sensações visuais. Defende que o real é a própria exterioridade, que não necessita de subjetivismos. Declara-se antimetafísico e contra a interpretação da realidade pela inteligência, justificando que a interpretação racional reduz as coisas a simples conceitos vazios: "Com filosofia não há árvores, há idéias apenas". Valorizando um objetivismo visualista, demonstra seu interesse pela natureza, pelo ritmo lento da frase, pelo verso livre, pela linguagem fluente, quase prosa, e pelas comparações simples e originais. Os seus versos apresentam, de maneira marcante, uma linguagem plástica ao descrever os cenários naturais, claros, amenos e extremamente sensoriais, valorizando sempre as percepções em detrimento da reflexão.

Segue abaixo o poema Num meio-dia de fim de primavera, presente na obra $O$ Guardador de Rebanhos, objeto de estudo para este artigo. 
Vi Jesus Cristo descer à terra.

Veio pela encosta de um monte

Tornado outra vez menino,

A correr e a rolar-se pela erva

$\mathrm{E}$ a arrancar flores para as deitar fora

$\mathrm{E}$ a rir de modo a ouvir-se de longe.

Tinha fugido do céu.

Era nosso demais para fingir

De segunda pessoa da Trindade.

No céu era tudo falso, tudo em desacordo

Com flores e árvores e pedras.

No céu tinha que estar sempre sério

E de vez em quando de se tornar outra vez

[homem

E subir para a cruz, e estar sempre a morrer

Com uma coroa toda à roda de espinhos

E os pés espetados por um prego com cabeça,

$\mathrm{E}$ até com um trapo à roda da cintura

Como os pretos nas ilustrações.

Nem sequer o deixavam ter pai e mãe

Como as outras crianças.

O seu pai era duas pessoas -

Um velho chamado José, que era carpinteiro,

E que não era pai dele;

E o outro pai era uma pomba estúpida,

A única pomba feia do mundo

Porque não era do mundo nem era pomba.

E a sua mãe não tinha amado antes de o ter.

Não era mulher: era uma mala

Em que ele tinha vindo do céu.

E queriam que ele, que só nascera da mãe,

E nunca tivera pai para amar com respeito,

Pregasse a bondade e a justiça!

Um dia que Deus estava a dormir

E o Espírito Santo andava a voar,

Ele foi à caixa dos milagres e roubou três.

Com o primeiro fez que ninguém soubesse que

ele [tinha fugido.

Com o segundo criou-se eternamente humano e [menino.

Com o terceiro criou um Cristo eternamente na cruz

E deixou-o pregado na cruz que há no céu

E serve de modelo às outras.

Depois fugiu para o sol

E desceu pelo primeiro raio que apanhou.

Hoje vive na minha aldeia comigo.

É uma criança bonita de riso e natural.

Limpa o nariz ao braço direito,

Chapinha nas poças de água,

Colhe as flores e gosta delas e esquece-as.

Atira pedras aos burros,

Rouba a fruta dos pomares

E foge a chorar e a gritar dos cães.

$\mathrm{E}$, porque sabe que elas não gostam

E que toda a gente acha graça,
Corre atrás das raparigas pelas estradas

Que vão em ranchos pela estradas

com as bilhas às cabeças

E levanta-lhes as saias.

A mim ensinou-me tudo.

Ensinou-me a olhar para as cousas.

Aponta-me todas as cousas que há nas flores.

Mostra-me como as pedras são engraçadas

Quando a gente as tem na mão

E olha devagar para elas.

Diz-me muito mal de Deus.

Diz que ele é um velho estúpido e doente,

Sempre a escarrar no chão

$\mathrm{E}$ a dizer indecências.

A Virgem Maria leva as tardes da eternidade a fazer [meia.

E o Espírito Santo coça-se com o bico

E empoleira-se nas cadeiras e suja-as.

Tudo no céu é estúpido como a Igreja Católica.

Diz-me que Deus não percebe nada

Das coisas que criou -

"Se é que ele as criou, do que duvido" -

"Ele diz, por exemplo, que os seres cantam a [sua glória,

Mas os seres não cantam nada.

Se cantassem seriam cantores.

Os seres existem e mais nada,

E por isso se chamam seres".

E depois, cansados de dizer mal de Deus,

O Menino Jesus adormece nos meus braços

E eu levo-o ao colo para casa.

Ele mora comigo na minha casa a meio do [outeiro.

Ele é a Eterna Criança, o deus que faltava.

Ele é o humano que é natural,

Ele é o divino que sorri e que brinca.

E por isso é que eu sei com toda a certeza

Que ele é o Menino Jesus verdadeiro.

E a criança tão humana que é divina

É esta minha quotidiana vida de poeta,

E é porque ele anda sempre comigo que eu sou [poeta sempre,

E que o meu mínimo olhar

Me enche de sensação,

E o mais pequeno som, seja do que for,

Parece falar comigo.

A Criança Nova que habita onde vivo

Dá-me uma mão a mim

E a outra a tudo que existe

E assim vamos os três pelo caminho que houver,

Saltando e cantando e rindo

E gozando o nosso segredo comum

Que é o de saber por toda a parte 
Que não há mistério no mundo

E que tudo vale a pena.

A Criança Eterna acompanha-me sempre.

A direção do meu olhar é o seu dedo apontando.

$\mathrm{O}$ meu ouvido atento alegremente a todos os [sons

São as cócegas que ele me faz, brincando, nas [orelhas.

Damo-nos tão bem um com o outro

Na companhia de tudo

Que nunca pensamos um no outro,

Mas vivemos juntos e dois

Com um acordo íntimo

Como a mão direita e a esquerda.

Ao anoitecer brincamos as cinco pedrinhas

No degrau da porta de casa,

Graves como convém a um deus e a um poeta,

E como se cada pedra

Fosse todo um universo

E fosse por isso um grande perigo para ela

Deixá-la cair no chão.

Depois eu conto-lhe histórias das cousas só dos [homens

E ele sorri, porque tudo é incrível.

Ri dos reis e dos que não são reis,

E tem pena de ouvir falar das guerras,

E dos comércios, e dos navios

Que ficam fumo no ar dos altos-mares.

Porque ele sabe que tudo isso falta àquela verdade

Que uma flor tem ao florescer

E que anda com a luz do sol

A variar os montes e os vales,

$\mathrm{E}$ a fazer doer nos olhos os muros caiados.
Depois ele adormece e eu deito-o.

Levo-o ao colo para dentro de casa

E deito-o, despindo-o lentamente

E como seguindo um ritual muito limpo

E todo materno até ele estar nu.

Ele dorme dentro da minha alma

E às vezes acorda de noite

E brinca com os meus sonhos.

Vira uns de pernas para o ar,

Põe uns em cima dos outros

E bate as palmas sozinho

Sorrindo para o meu sono.

Quando eu morrer, filhinho,

Seja eu a criança, o mais pequeno.

Pega-me tu ao colo

E leva-me para dentro da tua casa.

Despe o meu ser cansado e humano

E deita-me na tua cama.

E conta-me histórias, caso eu acorde,

Para eu tornar a adormecer.

E dá-me sonhos teus para eu brincar

Até que nasça qualquer dia

Que tu sabes qual é.

Esta é a história do meu Menino Jesus.

Por que razão que se perceba

Não há de ser ela mais verdadeira

Que tudo quanto os filósofos pensam

E tudo quanto as religiões ensinam?

(PESSOA, 2005, p. 28-33)

Para iniciar a análise é válido ressaltar que o poema escolhido é construído numa linguagem simples, ambientado em um cenário campestre caracterizado como sendo um lugar tranquilo, ameno e pretenso à claridade. Isto se nota já no primeiro verso do texto Num meiodia de fim de primavera, no qual os termos "meio-dia" e "primavera" remetem à claridade e alegria do lugar, características do espaço físico que influenciarão na integração e na comunhão do sujeito lírico com a natureza como forma de revelação lírica e expressão poética.

Desta forma, nota-se que o texto possui marcadamente a valorização sensorial, principalmente a visual, tendo como destaque o recurso da plasticidade poética. Isto se evidencia desde seu início, pois já no segundo verso Tive um sonho como uma fotografia, inicia-se a descrição do sonho comparando-o com uma fotografia, a qual se trata de um texto visual. Após esta comparação inicial as imagens são construídas através da descrição de 
várias cenas, sendo estas compostas através de muitos gestos e movimentos, o que facilita em muito o estímulo à imaginação do leitor, como ocorre nos versos: Vi Jesus Cristo descer à terra. / Veio pela encosta de um monte / Tornado outra vez menino, / A correr e a rolar-se pela erva / E a arrancar flores para as deitar fora / E a rir de modo a ouvir-se de longe. Neste último verso, a sugestão do som e do riso ecoando também auxilia em muito na criação da imagem, por parte do leitor, a qual também é sugerida através da descrição de cores que se contrastam, como nos versos: Ri dos reis e dos que não são reis, / E tem pena de ouvir falar das guerras, / E dos comércios, e dos navios / Que ficam fumo no ar dos altos-mares, ficando muito nítido o contraste entre a fumaça preta e o céu, possivelmente, azulado.

Outra técnica utilizada para a construção da plasticidade é a humanização do menino Jesus, notando-se a presença da profanação de alguns conceitos, pois segundo Agamben (2007, p. 65), o "profano, livre dos nomes sagrados, é o que é restituído ao uso comum dos homens." Deste modo, sugere-se ao leitor uma associação das imagens descritas pelo poea com as imagens corriqueiras familiarizadas em seu repertório pessoal, como nos versos:

Hoje vive na minha aldeia comigo. / É uma criança bonita de riso e natural. / Limpa o nariz ao braço direito, / Chapinha nas poças de água, / Colhe as flores e gosta delas e esquece-as. / Atira pedras aos burros, / Rouba a fruta dos pomares / E foge a chorar e a gritar dos cães. / E, porque sabe que elas não gostam / E que toda a gente acha graça, / Corre atrás das raparigas pelas estradas / Que vão em ranchos pela estradas / com as bilhas às cabeças / E levanta-lhes as saias. (PESSOA, 2005, p. 29)

Nota-se que as características de valorização do aspecto sensorial, a plasticidade e a forte carga sugestiva ao leitor, constantes nos poemas de Alberto Caeiro, são construídas através de estratégias textuais possuidoras de uma organização estrutural pré-estabelecida pelo poeta, as quais norteiam o leitor em relação as possíveis leituras. Em alguns momentos poderão ser mais ou menos restritivas à sugestão, à criação do leitor, com base em seu repertório particular. Esta organização estrutural é destacada nas teorias defendidas por Iser (1996, p. 159), pois segundo o teórico "as estratégias regulam no texto a organização dos elementos do repertório e asseguram as condições de recepção". Para Iser (1999, p. 149), "se o leitor produz relações entre os segmentos conectados, tal atividade precisa ser de alguma forma regulada".

Ficam evidentes nesta estrutura as lacunas que poderão ser preenchidas pelo leitor, permitindo-lhe “entrar' no texto e atualizá-lo com base em suas experiências, criando um caráter de acontecimento, mesmo que o texto cite fatos de outros tempos não vividos pelo leitor, mas que podem provocar algum efeito sobre ele. Assim, Iser afirma que os lugares vazios, 
sendo "pausas do texto", nada são; desse "nada", entretanto resulta um importante impulso da atividade constitutiva do leitor. Sempre aí, onde se justapõem os segmentos do texto, encontram-se os lugares vazios, interrompendo a organização esperada do texto. (ISER, 1999, p. 144)

Pensando em seu aspecto estrutural, o texto também possui algumas condições de lacunas, as quais são conhecidas na teoria de Iser pelo conceito de negação, o qual se caracteriza pelas lacunas criadas exigindo do leitor maior atenção e estimulando-o para que ele seja ativo e complete os espaços em branco do texto. Este recurso estrutural evidencia-se no poema, em versos como: É uma criança bonita de riso e natural / Limpa o nariz ao braço direito, / Chapinha nas poças de água, / Colhe as flores e gosta delas e esquece-as. Percebese aqui uma forte sugestão ao invés de uma mera descrição, pois a adjetivação bonita, por exemplo, é muito subjetiva e faz com que o leitor crie para si a imagem em questão, podendo imaginar a fisionomia do menino, a cor de seus olhos e de seus cabelos, ou o modo como ele está vestido. O tipo de flor que ele colhe para jogá-la fora também é apenas sugerido, não sendo definido se esta tem cor ou cheiro ou até mesmo espinhos. Assim, a criação destas imagens ficará a cargo do leitor, o qual complementará estas possibilidades do texto, pois como teoriza Eco (1994, p. 09) o escritor "alude a ele [texto literário] e pede ao leitor que preencha toda uma série de lacunas. Afinal, todo texto é uma maquina preguiçosa pedindo ao leitor que faça uma parte de seu trabalho".

Porém, por mais que o texto seja sugestivo, ele não abre a possibilidade para que seja feita toda e qualquer leitura, uma vez que o texto é organizado de modo a conduzir o leitor pelos possíveis caminhos a serem percorridos. Para uma leitura interessante "cabe, portanto, observar as regras do jogo, e o leitor modelo [ideal] é alguém que está ansioso para jogar" Eco (1994, p. 16). Este se trata de um aspecto essencial presente na teoria de Iser (1999, p. 172), pois para o teórico a relação entre texto e leitor "precisa ser de certa maneira guiadas, pois o leitor está aquém do texto e por isso tem de ser manobrado pelo texto para a posição adequada".

Sendo assim, o poema é estruturado de modo a utilizar o repertório do leitor ao fazer referência à convencional história de Cristo, o que se nota no verso Vi Jesus Cristo descer à terra, pois segundo a religiosidade cristã, Jesus Cristo encontra-se em um lugar acima da terra intitulado como Céu, sendo este um conceito muito comum para a população ocidental. Outras referências bíblicas ocorrem quando o menino Jesus descreve seu pai como sendo Um velho chamado José, que era carpinteiro, assim como na passagem associada à crucificação de cristo, como destacam os versos: Com uma coroa toda à roda de espinhos / E os pés 
espetados por um prego com cabeça, / E até com um trapo à roda da cintura. Deste modo, são sugeridas imagens ao leitor, este que provavelmente já possui outras imagens como parte de seu repertório e de sua percepção de mundo. Segundo Bosi

A experiência da imagem, anterior à palavra, vem enraizar-se no corpo. A imagem é afim à sensação visual. O ser vivo tem, a partir do olho, as formas do sol, do mar, do céu. O perfil, a dimensão, a cor. A imagem é um modo da presença que tende a suprir o contato direto e a manter, juntas, $\mathrm{s}$ realidade do objeto em si e a sua existência em nós. $\mathrm{O}$ ato de ver apanha não só a aparência da coisa, mas alguma relação entre nós e essa aparência: primeiro e fatal intervalo. (BOSI, 2008, p. 19)

Assim, as imagens construídas no poema de Caeiro visam desconstruir a imagem religiosa tradicional e criar uma nova imagem na mente do leitor. Desta maneira, para Iser (1999, p. 64), “a imagem representada de um objeto existente, porém ausente, pode ser controlada pelo conhecimento do objeto, ao passo que aquele objeto que introduz algo novo parece se subtrair ao controle". Deste modo, Iser destaca que

O leitor experimenta as associações de seu repertório de conhecimentos no estado da invalidação. Assim, o texto faz uso, através de seus esquemas, da história de experiências individuais de seus leitores, mas sob condições que ele mesmo estabelece. (ISER, 1999, p. 69-70).

Sendo assim, é através da criação destas imagens novas que o poema visa desconstruir a imagem de cristo e toda sua história bíblica tradicional presente no repertório do leitor. Pode-se notar isto nos versos:

No céu era tudo falso, tudo em desacordo / Com flores e árvores e pedras. / No céu tinha que estar sempre sério / E de vez em quando de se tornar outra vez homem / E subir para a cruz, e estar sempre a morrer / Com uma coroa toda à roda de espinhos / E os pés espetados por um prego com cabeça, / E até com um trapo à roda da cintura / Como os pretos nas ilustrações. / Nem sequer o deixavam ter pai e mãe / Como as outras crianças. / O seu pai era duas pessoas — / Um velho chamado José, que era carpinteiro, / E que não era pai dele; / E o outro pai era uma pomba estúpida, / A única pomba feia do mundo / Porque não era do mundo nem era pomba. / E a sua mãe não tinha amado antes de o ter. / Não era mulher: era uma mala / Em que ele tinha vindo do céu. (PESSOA, 2005, p. 28-29)

Percebe-se aqui, como tema, uma série de imagens encadeadas que desconstroem a imagem religiosa convencional presente no repertório do leitor fazendo com que, segundo Iser

No fluxo da leitura, o ponto de vista do leitor salte entre as perspectivas, de modo que o segmento que era tema se desloca para a posição de horizonte, fazendo com que seja focalizado aquele segmento que agora é tema. Dai resulta uma conseqüência importante para o processo de comunicação. (ISER, 1999, p. 150)

Para reafirmar o tema como desconstrução da imagem religiosa tradicional, nos versos que seguem da estrofe destacada, fica nítido o posicionamento enfático do eu-lírico 
quando diz: E queriam que ele, que só nascera da mãe, / E nunca tivera pai para amar com respeito, / Pregasse a bondade e a justiça!. Pessoa (2005, p. 29). Este recurso de utilização do tema para a construção de uma imagem nova da visão religiosa aparece também em outro momento posterior do texto, estruturado de modo semelhante, quando o eu-lírico retrata que o menino Jesus:

\begin{abstract}
Diz-me muito mal de Deus. / Diz que ele é um velho estúpido e doente, / Sempre a escarrar no chão / E a dizer indecências. / A Virgem Maria leva as tardes da eternidade a fazer meia. / E o Espírito Santo coça-se com o bico / E empoleira-se nas cadeiras e suja-as. / Tudo no céu é estúpido como a Igreja Católica. / Diz-me que Deus não percebe nada / Das coisas que criou — / "Se é que ele as criou, do que duvido" - / "Ele diz, por exemplo, que os seres cantam a sua glória, / Mas os seres não cantam nada. / Se cantassem seriam cantores. / Os seres existem e mais nada, / E por isso se chamam seres". (PESSOA, 2005, p. 30)
\end{abstract}

Ao retratar Deus como sendo um velho estúpido, doente e indecente, tem-se aqui o tema como desconstrução da imagem de Deus, o qual é visto tradicionalmente pela religião como um ser supremo, sem vícios ou defeitos. Uma descaracterização parecida ocorre com a Virgem Maria, a qual leva uma vida eterna entediada. O mesmo ocorre com a simbólica pomba do Espírito Santo, que se empoleira nos lugares sujando-os, o que pode ser lido como defecando à sua vontade instintiva, sendo retratada como uma pomba qualquer. Nota-se nesta desconstrução uma profanação da imagem religiosa convencional, sendo que o conceito de "profanação" utilizado neste estudo encontra-se embasado nas idéias de Agamben:

Os juristas romanos sabiam perfeitamente o que significava "profanar". Sagradas ou religiosas eram as coisas que de algum modo pertenciam aos deuses. [...] Sacrílego era todo ato que violasse ou transgredisse esta sua espacial indisponibilidade [aos homens]. [...] Se consagrar (sacrare) era o termo que designava a saída das coisas da esfera do direito humano, profanar, por sua vez, significava restituí-lo ao livre uso dos homens. "Profano" - podia escrever o grande jurista Tebácio - "em sentido próprio denomina-se que, de sagrado ou religioso que era, é devolvido ao uso e à propriedade de homens". (AGAMBEN, 2007, p. 65)

Nota-se que o poema de Alberto Caeiro trabalha não apenas com a profanação das imagens religiosas, feitas de maneira parodiada, mas também percebe-se a utilização de uma carnavalização dos valores presentes no repertório do leitor, pois evidencia-se a quebra das hierarquias convencionais ao se colocar Deus, a Virgem Maria e o Espírito Santo no mesmo plano de quaisquer mortais cheios de imperfeições. Em relação a este recurso de carnavalização, segundo Bakhtin,

Elimina-se toda distância entre os homens e entra em vigor uma categoria carnavalesca específica: o livre contato familiar entre homens. [...] A excentriciadade é uma categoria específica da cosmovisão carnavalesca, ela permite que se revelem e se expressem os aspectos ocultos da natureza humana. [...] [assim] 
entram nos contatos e combinações carnavalescas todos os elementos antes fechados, separados e distanciados uns dos outros pela cosmovisao hierárquica extracarnavalesca. O carnaval aproxima, reúne, celebra os esponsais e combina o sagrado com o profano, o elevado com o baixo, o grande com o insignificante, o sábio com o tolo. A isso está relacionada a profanação. (BAKHTIN, 2002, p. 123)

Fica evidente então que desta forma o texto modifica o já conhecido, mostrando a possibilidade de uma imagem nova e de outra versão de "mitos" já solidificados. Para isto, também se usa o recurso de se inserir coisas e fatos que não estavam presentes originalmente:

Um dia que Deus estava a dormir / E o Espírito Santo andava a voar, / Ele foi à caixa dos milagres e roubou três. / Com o primeiro fez que ninguém soubesse que ele tinha fugido. / Com o segundo criou-se eternamente humano e menino. / Com o terceiro criou um Cristo eternamente na cruz / E deixou-o pregado na cruz que há no céu / E serve de modelo às outras. / Depois fugiu para o sol / E desceu pelo primeiro raio que apanhou. (PESSOA, 2005, p. 29)

Com base no exemplo destacado podemos notar o que Iser intitula como desvios do texto, os quais "podem abranger a violação da norma e do cânone até a extinção do valor do familiar. Desse modo, o potencial semântico do texto aumenta, e esse aumento se manifesta como tensão.” (Iser, 1996, p. 164)

Esta tensão criada pelo choque entre os conceitos novo versus velho, no poema, é reforçada no fechamento do texto de maneira enfática e questionadora: Esta é a história do meu Menino Jesus. / Por que razão que se perceba / Não há de ser ela mais verdadeira / Que tudo quanto os filósofos pensam / E tudo quanto as religiões ensinam? (Pessoa, 2005, p. 33)

Estas séries de recursos descritos anteriormente servem como estruturas que visam trazer como tema algo novo, em contraste com os conceitos já presentes no horizonte do leitor, o qual terá que assimilar o tema tratado para depois transformar a descoberta através das leituras, requerendo, assim, uma postura ativa. Deste modo, no momento em que a obra está se realizando, a relação entre texto e leitor é algo virtual e têm-se o tema. Após isto, caso haja a apreensão e reflexão do conteúdo, este que era tema passará a ser o horizonte do leitor. Então

O papel do leitor torna-se mais concreto, pois ele terá de ocupar pontos de vista, de modo que o lugar do leitor, lugar ainda vazio e aquém texto, deve ser até certo grau preenchido. [...] ele é cada vez mais forçado a escolher entre pontos de vista. [...] [então] instala-se o equilíbrio entre hábito e descoberta quando o hábito é corrigido, e assim a descoberta ganha sua função. (ISER, 1999, p. 180)

Porém, se o leitor assume a postura de insistir em seus hábitos e conhecimentos anteriores à leitura, perde o que tinha descoberto. No entanto, se assume a posição de sua descoberta, o hábito se torna tema para a observação. Desta forma, ocorre o que Iser intitula 
como sendo uma negação secundária, quando o leitor é impelido a ligar a descoberta a seus hábitos, a refletir sobre suas atitudes. Sobre este aspecto Nunes ressalta a importância da leitura literária ao destacar que "a importância ética da leitura está no seu valor de descoberta e de renovação para a nossa experiência intelectual e moral. A prática da leitura seria um adestramento reflexivo, um exercício de conhecimento do mundo, de nós mesmos e dos outros” Nunes (1998, p. 175). Para que este exercício de reflexão aconteça, é necessária uma composição estrutural na obra que possibilite isso. Por este motivo, Nunes teoriza que

\section{A obra literária vem a ser a linguagem organizada em "camadas" múltiplas que se articulam harmonicamente, como as partes de uma polifonia, num só efeito estético de conjunto. Mas essa polifonia só existe quando executada pelo leitor. (NUNES, 1998, p. 180)}

Sendo assim, após esta realização de interação entre texto e leitor o conceito de efeito estético se configura. O leitor já não será mais o mesmo, visto que suas experiências antes da leitura foram alteradas de uma ou outra forma, modificando-o em algum aspecto. Em conseqüência disto, o efeito estético só existe após a leitura concretizada pelo leitor, e será após este ato que a existência do prazer estético se efetivará fora do texto que possui um receptor ativo, visto que o prazer estético pertence ao leitor, sendo desta forma algo subjetivo.

Sobre o efeito estético de um texto pode-se então concluir, como atesta Iser, a observação de que a primeira e principal condição do "efeito" é a sua recepção pela “compreensão na sucessão de seus versos, sua narração ou o seu deslocamento dramático". O segundo passo é a interpretação, denominada por Jauss de "concretização de uma significação específica”, ligada à primeira leitura, mas com tarefa objetiva e mais direcionada ao esclarecimento da construção do texto (as condições verbais e poéticas) que orientam e conduzem a compreensão. A última etapa é a aplicação, na qual as anteriores estão incluídas, na medida em que representam o interesse de transpor o texto fora de seu passado ou dentro de seu presente, formando um julgamento estético que persuada e convença com precisão os possíveis intérpretes.

Entende-se, ainda, que a obra que surge não se apresenta como novidade num espaço vazio. Deverá ficar o leitor atento aos avisos, aos códigos, aos sinais visíveis e invisíveis, aos traços familiares, às indicações implícitas, despertando a lembrança do já lido, conduzindo-o a certa postura emocional, antecipando a compreensão e direcionando a subjetividade da interpretação. 


\section{Conclusão}

Evidencia-se a grande importância do referencial teórico proporcionado pela Estética da Recepção, o qual auxiliou em muito os estudos teórico-críticos relacionados aos textos artísticos. No entanto, sabe-se que um texto rico como este não está esgotado em suas possibilidades de leituras, podendo vir a ser revisitado com base em outras teorias e leitores com os mais variados repertórios. Assim, nota-se que a vida é composta de referências e releituras de determinadas situações. Deste modo, quem possui mais conhecimento, leituras, experiências, um universo mais amplo e maior contato com as variadas áreas do conhecimento, tem muito mais chance de percebê-las.

\section{Agradecimentos:}

A todos professores e familiares que contribuíram de maneira direta ou indireta para a realização deste estudo, em especial à orientadora Dr. ${ }^{a}$ Clarice Zamonaro Cortez, e à CAPES pela bolsa de mestrado concedida.

\section{Referências}

AGAMBEN, G. Profanações. In: Elogio da Profanação. Tradução Selvino José Assmann. São Paulo: Boitempo, 2007.

BAKHTIN, M. Problemas da poética de Dostoievski. 3. ed. Tradução Paulo Bezerra. Rio de Janeiro: Editora Forense Universitária, 2002.

BOSI, A. O ser e o tempo da poesia. 7. ed. São Paulo: Companhia das Letras, 2008.

ECO, U. Os seis passeios pelos bosques da ficção. $6^{\mathrm{a}}$ reimpressão. Tradução Hildegard Feist. São Paulo: Companhia das Letras, 1994.

ISER, W. O Ato da Leitura: uma Teoria do Efeito Estético. Vol. 1. Tradução Johannes Kretschmer. São Paulo: Editora 34, 1996.

O Ato da Leitura: Uma Teoria do Efeito Estético. Vol. 2. Tradução Johannes

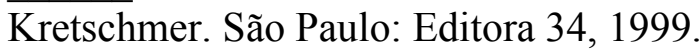

JAUSS, H. R. O Prazer Estético e as Experiências Fundamentais da Poiesis, Aisthesis e Kathersis. In: A Literatura e o Leitor: textos de estética da recepção. Coordenação e tradução de Luiz Costa Lima. Rio de janeiro: Paz e Terra, 1979. 
MOISÉS, M. A Análise Literária. 8. ed. São Paulo: Cultrix, 1987.

NUNES, B. Crivo de papel. São Paulo: Ática, 1998.

PESSOA, F. Poesia completa de Alberto Caeiro / Fernando Pessoa. Edição Fernando Cabral Martins, Richard Zenith. São Paulo: Companhia das Letras, 2005.

QUADROS, A. Fernando Pessoa: vida, Personalidade e Gênio, 2. ed. Lisboa: Dom Quixote, 1984.

[Recebido em junho de 2011 e aceito para publicação em outubro de 2011]

The routes to be followed into Alberto Caeiros's poetry: a reception aesthetics approach

Abstract: The aim of this article is to study the $8^{\text {th }}$ poem Num meio dia de fim de primavera written by Alberto Caeiro. The analysis proposed will be based on some of the Reception Aesthetics concepts mainly focusing on enriching the sensory aspects of the text, especially the visual one. For that purpose, the poetic devices used in the construction of the text as well as its reception by the readers will be highlighted. The analysis will be based on the concepts theorized by Wolfgang Iser. Such concepts are: a) the interaction between text and reader and the position of the latter at the time of the former reception; b) the blank places; c) the negation and negativity structures; and d) it will also consider the approach to reading as an act in which the reader is responsible for achieving the meaning for the text and for creating an "aesthetic pleasure" through it. This last concept is grounded in Hans Robert Jauss theory. Keywords: Reception aesthetics. Portuguese poetry. Interaction between text and reader

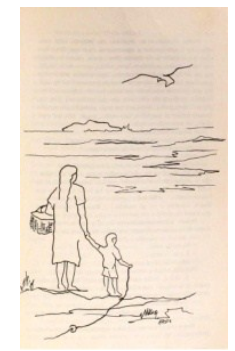

